\title{
China's New Agricultural Revolution
}

\section{Jack Gray}

\section{The Nature of the New 'Responsibility Systems'}

Collective agriculture in China has now run the whole gamut of the possibilities of socialist farming, producing a richer variety of experience than in any other communist country. China has moved from the mutual-aid teams and service co-operatives of 1951-53 to the abruptly enforced Soviet-kolkhoz style of collective of 1956-57, to the communes of 1958-59, to the 'three-level ownership' of 1960, to the looser sanzi yibao ${ }^{1}$ experiments of 1962-65, to the reassertion of commune-style collectivism in the Dazhai movement, and over the past two years to the encouragement of 'production responsibility systems'.

The plural 'systems' indicates their variety, and the flexibility with which they are meant to be applied, but the central thrust is clear. It is the substitution of contracts for the subordination of the commune members to the leadership in day-to-day farming operations. Groups, households or individuals enter into output contracts with the team; it should be stressed that these are not contracts to plough or hoe so much land, or to perform other partial tasks; they are for the final output. Most commonly, the farming household, or a group of households, contracts for a given output; any surplus over the contracted amount is divided between the household and the collective in proportions agreed in the contract. All production is subject to unified distribution by the team or brigade leadership, though in conformity with the contract. Although the labour involved in meeting the contractual obligation is often initially calculated in work-points, the value of the work-point no longer varies as formerly with the total production of the collective; the calculation is simply the preliminary means of arriving at an equitable contract, to ensure for example that the family working full-time on raising rabbits for export does not earn unconscionably more for an hour's labour than the family growing grain.

Two and a half years of experiment in China's endlessly differing local conditions has produced a perplexing variety of arrangements and combinations.

\footnotetext{
${ }^{1}$ Literally, 'three selves, one contract': more private plots, more free markets, more enterprises on a profit or loss basis, and giving output
} quotas on a household basis.
To clarify the picture, we should make some distinctions.

First, there is a distinction between arable farming and items of diversification, traditionally called 'sidelines'. The latter include care of animals and poultry, vegetable-growing, forestry, fish-raising, handicrafts. To encourage diversification and increase local crafts and industries in order to reduce surplus rural labour and maximise peasant incomes, a division of labour is now seen to be necessary. Also, to increase labour productivity a degree of specialisation is needed. Hence there is a move away from the idea that every labourer must devote his normal working day to participation in the growth of grain. It is now acceptable that some may spend their full time in some other line of production. The contract system was therefore applied first to activities other than arable farming. Subsequently in some areas it was applied also to grain growing; for once it is accepted that some members of the collective can specialise in raising poultry or taking care of the team's orchard, it is difficult to resist the idea that grain also might be advantageously grown by 'specialist' groups or households in the same way.

Second, there is the obvious distinction as to the unit rewarded for labour or output - the production team (specialised within a brigade), the work group, the household or the individual labourer.

Third, there is the basis of remuneration - fixed remuneration for an assigned task; remuneration for an assigned task with rewards and penalties for over or under fulfilment; remuneration for contracted output; profit sharing; and individual enterprise subject only to taxes, levies and procurement.

Fourth, there is the task for the performance of which remuneration is given: piecework, target, quota, contract, or (virtually) the payment of 'rent' and taxes.

Fifth - and perhaps the most critical for the future of collective agriculture - there are distinctions in the way in which the product of team members is 


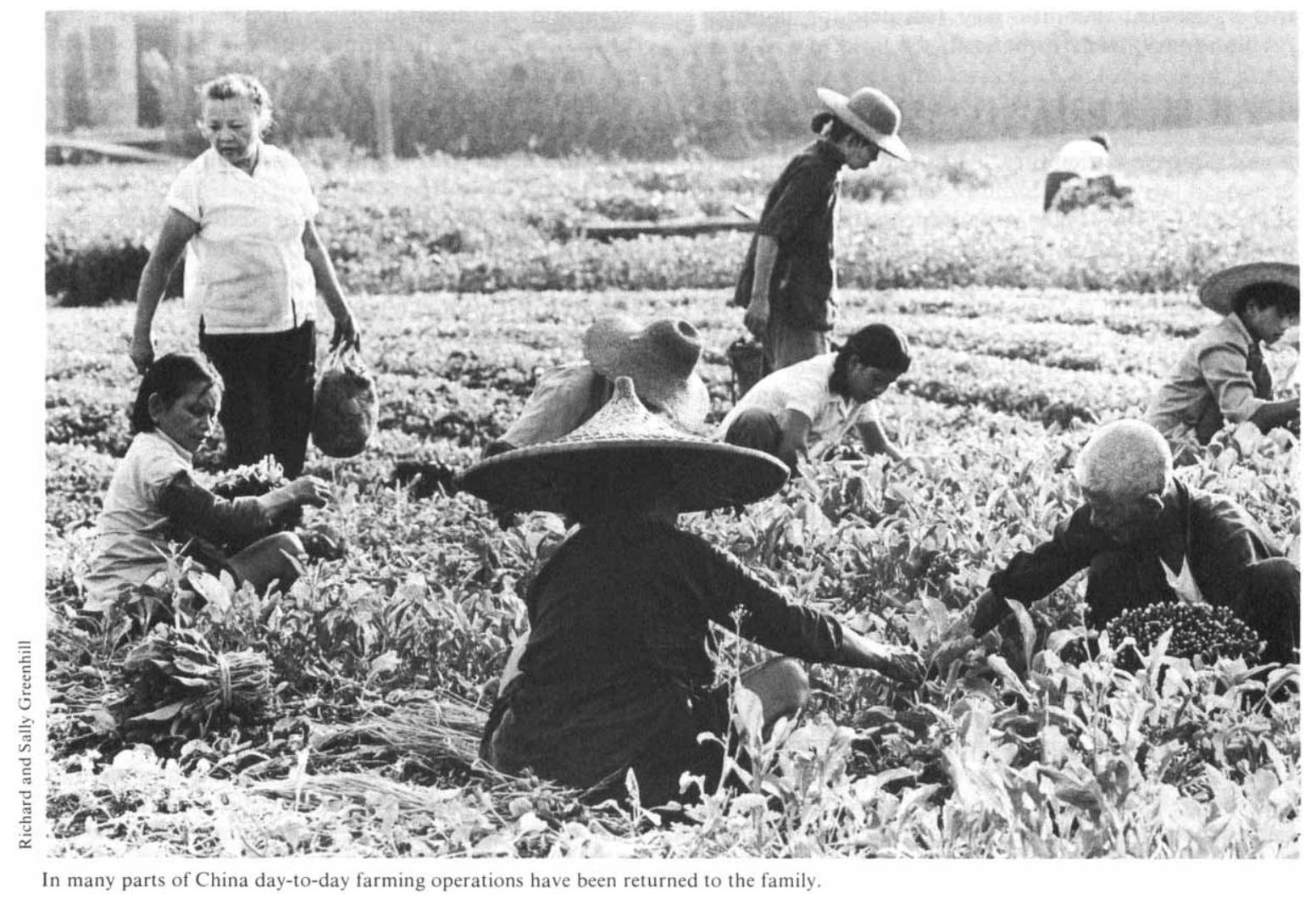

distributed: unified accounting and distribution of the whole product (except for that of private plots and private sidelines); unified distribution of quota production; unified distribution of communal levies on and profits from contractors; and in the case of the system of 'full responsibility to the household for task completion', little or no communal distribution except in the form of the social wage represented by welfare, health and cultural services where such exist or continue to exist.

Sixth, there is the division of teams into poor, middling and successful. In the first stages of the introduction of the responsibility systems, this distinction was critical. It was argued that in successful teams relatively little change in the organisation of production and the remuneration of labour was necessary, except to slough off the Dazhai inheritance. However, in the poorest teams, where (ironically) collectivisation had proved to be a source of burdens rather than of benefits, a return to some form of family farming was appropriate. Middling teams had the choice of a range of intermediate possibilities, mostly involving group, household or individual quotas or contracts. This distinction has now worn rather thin. In the successful teams, because prosperity and the degree of diversification tend to be related, there is actually maximum scope for specialised contracting, in which arable farming soon becomes involved. And at every level, the strong desire of the majority of peasants -or, to be more cautious, of at least a minority strong enough to enforce the desired changes - to maximise their independence as producers has had an impact on the results. The various forms of individual and household cultivation have clearly grown far beyond the original 1979 idea that such an unsocialist mode of production was permissible only for a few remote and scattered farms, which had probably never in practice operated as a part of the collectives in any case.

\section{Problems in Previous Agriculture Policies}

It might seem, at least at first sight, as if collectivised agriculture in China were well on the way to near-total collapse. It would also seem that the new system (if it is indeed a system) is at virtually all points in contrast to the Maoist inheritance. To reach a conclusion on these issues, it is necessary to discuss the reasons given by 
Deng Xiaoping and his supporters for undertaking this sweeping, revolutionary (or perhaps counterrevolutionary) transformation.

It is not unreasonable that the Party and Government of China should be discontented with the progress so far of Chinese agriculture. Although production has increased at a commendable rate overall and has somewhat more than kept pace with population growth, the situation is still far from acceptable. The scarcity of grain is still a tight constraint on both development and the increase of welfare. Growth has been erratic, and the present leaders of China point to the fact that the worst periods from this point of view have been those in which the left was in power and put its egalitarian policies into operation [Yu Gaoyao 1980:28]. ${ }^{2}$ During the period of leftist dominance, official policies had hampered the growth of agricultural output by giving absolute priority to grain and neglecting - or even condemning - diversification. The results of the vast campaigns which have characterised the rural scene since 1949 are now questioned. Finally, while conceding that agricultural production continued to rise during the Cultural Revolution decade, critics now point out that peasant incomes failed to rise in proportion and in some areas even decreased in spite of increased output. The Communist Party's official newspaper, People's Daily, calculated that among $100 \mathrm{mn}$ peasants collectivisation had failed to raise production significantly during a period when population as a whole had doubled [Renmin Ribao 1980a]. Average rural incomes remained far below average urban incomes; the rural 80 per cent of the population received only 20 per cent of national income. Indeed, it has been estimated that in one in six of China's 2,000 or so counties the peasants had 'lost faith in the collective', and where this was so, it was necessary to allow them to return, for the present, to family farming [Renmin Ribao 1980b].

The present diagnosis of past failures can be summarised as follows:

1) Investment had been pushed to unrealistically high levels in an attempt to improve agriculture, but with poor results. Zhan $\mathrm{Wu}$, director of the Agricultural Economics Institute of the Chinese Academy of Social Science, has estimated that irrigation works were less than 50 per cent effective; moreover, that while from 1965 to 1977 capital

\footnotetext{
${ }^{2}$ Preference has been given in the quotation of sources to materials available in translation, and especially to the monitoring reports of Chinese broadcasts published by the BBC (Summary of World Broadcasts, part 111, The Far East) and the FB1S (China Daily Report). These have the advantage of including coverage of provincial as well as central material, particularly valuable for the subject of this essay. These are referred to as $\mathrm{S}$ (BBC/SWB) and F (FBIS) respectively.
}

invested in farm machinery had increased over eightfold and chemical fertiliser supplies had grown by almost two and a half times, and while farm costs had increased by 130 per cent, production had risen by only 80 per cent. Zhan emphasised that increased investment is not the only way to speed up development' [Guangming Ribao 1980].

2) The level of management ability among many rural cadres is very low. ${ }^{3}$ Some teams have no accountants; some leaders have worked for 10 years without even an account book. Others combine the posts of team leader, accountant, work-point recorder and store-keeper. Many teams do not know what they have spent in materials, money and labour, and have no means of judging the return on expenditure. There is little or no democratic discussion of collective accounts. The level of waste is described as 'appalling', and there is every opportunity for privilege and peculation because cadres need not make any distinction between their public business and their private interests. Rural cadres also have little knowledge of modern scientific methods. They are former peasants, mostly recruited during land reform and collectivisation, they are ageing rapidly, and there is little prospect of their replacement by younger men with greater knowledge and new ideas because too few of the inadequate number of graduates in agriculture are willing to serve in the villages. Grass-roots cadres are largely incapable of taking decisions for themselves, and the institutional framework - in which commune-level cadres are salaried servants of the state - actually discourages initiative; the safest course is to obey orders.

3) The burdens imposed on the peasants are heavy, unpredictable and counter-productive. ${ }^{4}$ In some cases the total handed over to the team, brigade, commune and state in taxes, levies, accumulation etc is over 50 per cent of gross production, and in this respect the poorer teams - less able to support this wasteful superstructure - suffer most. The first burden is the uncontrolled investment already alluded to. The second is the swollen administration, the number of cadres suported by 'subsidies' and enjoying from this source incomes often two or three times as high as those of the peasants. The third burden arises from the abuse of the state monopoly of trade; procurement norms are raised in good years or prices reduced [Renmin Ribao 1981a] so that 'the more enthusiastic

\footnotetext{
${ }^{3}$ On the faults ascribed to grass-roots cadres, see especially S/6568/BI1/5, Renmin Ribao, 3/11/80; F/253/L42, Renmin Ribao 13/12/80; F/238/T2, Hong Kong Ming Pao, 6/12/81, reporting Xin Guancha.

${ }^{4}$ On peasant burdens, see especially: F/225/20/11/79. Renmin Ribao 6/11/79. S/6479/BII/1. Guizhou 20/7/80; F/145/T. Renmin Ribao 11/7/81; S/6814/BII/1. NCNA (Chinese) 25/8/81. 5/6826/C.3. NCNA (Chinese) 4/9/81; S/6843/BII.2. Renmin Ribao 17.9.81.
} 
you have been, the greater your burden'. Supply and marketing co-operatives play the same game of forcing prices down in times of plenty, while the peasants are not allowed to seek an alternative buyer. Not only the team leadership but the higher levels also put in their claims on the incomes of production teams. It is in fact normal for over 30 per cent of gross production to be siphoned off before any distribution of the product is made to the peasants; this is about the same proportion of total farm incomes as was taken by the landlords from their tenants before the revolution.

4) The authorities re-allocated peasant resources 'in violation of exchange at equal value', [Renmin Ribao 1980c] with no respect for the rights of ownership of individuals or of teams.

5) The problem of distribution, 'to each according to his labour', has never been solved. The piecework and job contract system which was used in imitation of traditional Soviet methods was not satisfactory; quality of work could not be controlled. The free supply system of the Great Leap Forward, however, was far worse: the labourer received much the same income whether he worked hard or not. The Dazhai system of self-assessment was similar and people came to think that they would get the same regardless of how they worked. Though methods of work assessment were tried in some places, they proved inadequate in measuring accurately the quality of the performance of a farm task involving so many people, because for most of the year farm tasks cannot be expressed in terms of output. It has frequently been pointed out that productivity on the private plot, where incentives are not impaired, is much higher than on the collective fields, and represents the intensive and meticulous cultivation which China must achieve on all her farmland.

6) The suppression of private plots, rural fairs and family sideline occupations severely limited peasant incomes. The obsession with growing grain prevented the team or the brigade from pursuing similar sources of profit collectively. These restrictions, by reducing incomes, also reduced the possibilities of accumulation, which in turn limited the improvement of arable farming; this was reflected in the failure of incomes to rise substantially and the result was to depress incentives still further: "who wants to do unprofitable work?' said the peasants. Many deserted the collective farm for itinerant peddling or craft work.

\section{Rationale for the Introduction of 'Responsibility Systems'}

The responsibility systems are believed to be the cure for these ills. They should be seen in the context of more general changes in agricultural policy. These include the recent increases in procurement prices and decreases in the price of farm inputs; the enlargement of private plots and the provision in addition, according to circumstances, of fodder plots, grain ration plots and hill plots for the growing of timber, fuel, fruit and tea; the partial freeing of rural markets; the encouragement (instead of repression) of individual and family sideline production; measures to increase investment in light industry in order to increase the flow of incentive goods; increased investment in agriculture, especially investment by local authorities; diversification of agricultural and rural production; and - last but not least - the democratisation of collective management.

Behind this range of policies lie certain assumptions about the strategy of rural growth: that increased peasant purchasing power is a major - if not the major - driving force of national economic development; that therefore priority in state investment should be given to agriculture; that all the potentialities of each local community must be exploited in order to increase income and so increase the possibility of local investment; that in this last process, local collective industrialisation has a key role to play as the major means of raising capital for the transformation of agriculture; and that local potentialities can be fully developed only if the process is a democratic one, in which the grass-root communities and their individual members are given the maximum freedom of decision-making compatible with general - and largely indicative - socialist planning.

These assumptions are all derived from the thought of Mao Zedong. The strategy has not changed; what has changed is organisation, as a result of the conviction that previous policies and institutions unnecessarily minimised incentives. The agonies of the culturalrevolution struggle led to re-thinking about the nature of socialist organisation, in the course of which some hitherto sacrosanct assumptions were rejected. The new leaders deny that there is something intrinsically socialist in collectivising everything and on the largest possible scale. Scale alone does not create economies if there is no division of labour and no specialisation and co-operation in any meaningful sense. Such a system incurs the inevitable wastes of large-scale production while offering none of its advantages. As the Chinese put it, to allow production relations to outrun the development of productive forces is positively counter-productive.

Second, they affirm that it is the content of collectivisation which matters. To allow collectivisation outrun the development of management ability, accounting skills, technology, the willingness of prosperous communities to share with adjacent 
poorer communities, and political consciousness generally is also counter-productive. Mao's speedy collectivisation in 1955 and 1956 is now condemned as a 'strategic failure'; the 1958 destruction of the marginal economic independence left to the peasants in the form of private plots and rural fairs is denounced as an excess; the merging of rich and poor teams in single units of account and distribution is rejected; and the ideological identification of collectivism with one particular form of labour organisation - large-scale direct management by the collective leadership - is repudiated.

The responsibility systems aim, among other things, to substitute temporarily for this ideal and final type of socialist mass production a pattern of specialisation based on existing, largely manual, technology through the system of contracts. It is argued that this is not a retreat but an advance, because division of labour will stimulate technological change. The case of 'full responsibility to households', however, is frankly admitted to be a case of reculer pour mieux sauter, not 'a communist aspiration'.

The new contract systems are seen as representing a single, key change which can solve many problems of collectivisation. The specialisation and division of labour provide a form of organisation which can deal with the urgent need for diversification. It improves incentives in collective production. Where successful, it makes private plots unnecessary, thus eliminating a major conflict of interest. It minimises managerial overheads and the effects of managerial incompetence. It is simple and comprehensible. It cuts down the need for collective accounting and reduces the possibility of waste and peculation by ensuring that most of the accounting is done in terms of the negotiation of contracts, during which peasants as individuals and as a team can defend their financial rights and interests. Finally, it is democratic.

This last point - the political implications of responsibility systems - is given equal stress with the economic implications. A suitable responsibility system 'can encourage members to increase their independence and their initiative, and free cadres from their unnecessary task of "disciplining" people" [Renmin Ribao 1981b]. An attempt is being made to create an effective framework to protect the rights and interests of teams against higher authorities, and of members against the team. For instance, Shanghai suburban communes have begun the election of management committees, to give members 'the minimum necessary guarantee for exercising their democratic rights'. Elsewhere, provisions have been made to ensure democratic discussion of and control over collective financial policies.
In the choice and implementation of responsibility systems, it has been repeatedly stressed that the decision lies with the team members; they should be guided but not coerced. Cases have been widely publicised where the team party committee has been severely reprimanded by higher party authority for attempting to force a particular system on its members. This insistence on democratic decision has been taken to the point of accepting that even a majority decision of the team's members should not necessarily be imposed on a dissenting minority; teams may use different responsibility systems at the same time, so that members can enter into any reasonable relationship with the collective.

The most interesting feature of the whole movement is the admission that the operation of rural economic life by a party hierarchy, whose members owed no responsibility to anyone except their hierarchical seniors, has been not only politically dangerous but economically counter-productive. In agriculture as in industry, China now seeks to replace central party direction by a combination of controls - indicative planning, market discipline and democratic control from below.

Even the commune system itself has been under fire as economically irrational and undemocratic. According to an article in the journal Economic Management, communes have encouraged over-accumulation, and over-hasty transition to larger collectives flouted the rights of the basic-level production teams, drained their resources and restricted their economic and political initiative. The commune system has also been criticised for fusing, and thereby confusing, economic management and governmental administration. The result is a proposed reform which abolishes the system of three-level ownership and vests full ownership rights in the teams, and which redefines the commune as an economic corporation, assigning its previous governmental functions to a revived local government unit (xiang). Such an experiment was under way by late 1981 in Fengyang county, Anhui Province.

The communes, therefore, may very soon be abolished; the most famous institution of Chinese socialism may disappear. If so, there would be losses as well as gains, and perhaps a more considered diagnosis of their failings would recognise that the fault lay not in the commune system itself but in the undemocratic domination of the three levels by the state party hierarchy; and the consequent change of the three levels of communal ownership (a concept quite compatible with democratic control) into three further levels of the centralised hierarchy. 


\section{Impact and Implications of the New Policy}

Local reports of the operation of the responsibility systems show striking increases of production and incomes. Caution is needed, however. We had no lack of striking examples of success from the communes of 1958 and from the Dazhai model and its imitators in the 1970 s, examples which were probably true but not necessarily typical. Widespread resistance to the new system obliges its supporters to redouble their propaganda. Moreover, it should never be forgotten that in China's climatic conditions it is difficult to judge the effects of any agricultural policy over less than a period of ten years; and so far none of China's successive policies has ever been allowed to run unchanged for so long. More convincing, perhaps, than selective accounts of dramatic success is the report of a crash programme in Anhui Province to build extra grain-storage capacity, after two years of the responsibility systems. Significant too is the unprecedented boom in rural house-building. Such information gives some credence to the reports from 11 provinces of striking increases in almost all branches of agriculture, in rural incomes and in the amount of grain marketed. National production figures also suggest that agriculture has progressed at a sharply increased pace, although the information is not such as to make it possible to give any one part of the complex of new policies the greatest credit.

The local examples of success express the expectation that not only will grain production increase rapidly, but also, and even more rapidly, the production of 'diversification items'; not only production, but incomes; and not only the incomes of those already prosperous, but the incomes of the poorest, and perhaps these will increase faster. Examples are already being given of the increased ability to face famine of those teams which have most successfully diversified production via the responsibility system.

Nevertheless, there has been, and continues to be, much resistance to the new policies. The picture one gets is of reluctant middle and lower rural cadres being squeezed between the upper millstone of a leadership determined on change, and the lower millstone of peasant communities only too ready to accept it. In May 1980, People's Daily complained that 'many local authorities are stubbornly hanging on to their power to plan sowing and planting and to handle and process products. They fear being unable to "exercise control" [Renmin Ribao 1980d]. The resistance at lower levels was partly the expression of vested interests. Some cadres, it was said, understood and agreed with the policies, but resisted implementing them because 'there was nothing in it for them'. One cadre, talking to the Party Secretary of his Prefecture, frankly said: 'If you assign households full responsibility for task completion ... what am I going to eat?'

People's Daily itself admitted that the new system had its dangers to socialism and listed ten [NCNA 1980]. They were:

- purchase, use, maintenance, repair and management of large machines and tools;

- unified and rational use of water resources;

- care of draft animals;

- prevention of pests and diseases;

- popularisation of scientific farming;

- defence against natural disasters;

- farmland capital construction;

- commune and brigade enterprise and diversification;

- water and soil conservation;

- care of the needy.

The author of the article might well have added danger to the implementation of family planning, to the maintenance of rural employment, and most significant of all, to the very existence of collectivised farming.

With the proponents of change in full control of the media, one can scarcely expect a great deal of evidence to be published at this point supporting the fears expressed in People's Daily. Inevitably, the tendency has been to give examples showing that such fears are illusory, that these problems are not inherent in the responsibility system and can be solved by good administration. It is too early to evaluate this optimism and the evidence so far is ambiguous. On irrigation, for example, it has been suggested that the application of the responsibility system will actually improve the effective use of water. The change in the organisation of farming will in any case scarcely affect large and medium catchment areas, but only small village networks. The effect on the care of draft animals cannot yet be estimated. Depending on the form of responsibility in operation, they may be allocated under unified management, hired out to the contracting peasants, allotted on long loan to contractors, or in some cases sold to households operating the full responsibility system. Contracts are expected to guarantee the care and protection of animals, and if the contracts are sensibly drawn up care of animals might well improve.

A return to farming operated by individual families could jeopardise pest and disease control, but examples are given of household farming contractors forming organisations of neighbours to carry out spraying. 
Innovation is being encouraged by contracts between teams, groups or households and the extension stations, by which the extension station will take the risks and share the profits. It is hoped that this will represent a vast improvement on the present situation in which 'the peasants doze while the leaders shout themselves hoarse propagandising new techniques'.

Another fear expressed by the People's Daily was that defence against natural disasters would suffer. This is to assume that such defence depends solely on the ability to mobilise the necessary labour, which may indeed be impaired by the greater independence of both teams and members. But defence depends in the long run as much on the increase of production and so of reserves, on diversification so that peasants do not have all their eggs in one basket, and on the capacity to accumulate funds for irrigation and flood control which depends again on increased production and incomes, all of which (the supporters of change would argue) can best be delivered by the responsibility systems.

The threat to the maintenance of social security services is serious enough for the state council to have issued a circular on the subject. There is plenty of evidence from areas where full responsibility to households is widespread that there is some difficulty in inducing the peasants to meet their social obligations, such as contributions to the payment of teachers and barefoot doctors. Those who favour the responsibility system argue that as production and incomes increase so will the ability of teams to accumulate, and those in distress can then be better provided for.

In the end, the overcoming of such problems depends on the successful maintenance of the necessary degree of 'collective' control, which could be exercised by the team or by a reconstituted local political authority, or by a division of responsibilities between the two. The problem here is primarily with the systems which give contracts for arable farming to households, or give them full responsibility. Here, there is a manifest danger, amply illustrated in the records, that the peasants will use their autonomy to resist their remaining responsibilities. It is clear that the leadership regards the responsibility systems not as a surrender to individualism, but as a re-articulation of collective responsibilities. Ownership remains with the production team; land allotted to contractors is to be used only for the purposes specified in the contract and it cannot be bought, sold, pledged or rented out or in, nor can it be built upon or used as a source of clay, sand or minerals. Normally, means of production such as tools allotted for use are hired to the contractors or if allotted free are subject to the payment of a depreciation charge. It is emphasised that land must be distributed according to labour power, with or without some modification to take account of dependents, and it should on no account be allotted according to the individual holdings of the post-landreform period.

Planning is expected to remain firmly in the hands of the collective. The team is free to choose what it sows, plants or manufactures, vis-à-vis higher authorities, though subject to the state's 'reference plans'. The team members do not have such freedom. The team plans production and allocates responsibilities within this plan to groups, households and individuals.

The collective is expected to continue the process of accumulation of collective capital, although in the poorer areas it is accepted that little or no accumulation can be expected in the near future until the economic wounds of the past have healed. With this exception - a large exception it must be said - it is laid down, though as an expectation rather than a rule, that abour 20 per cent of net income [Renmin Ribao 1980e; Shanxi Ribao nd] will be accumulated for all purposes: next year's production expenses, overhead costs, welfare funds and funds for 'expanded reproduction'. In all cases except that of the assignment of full responsibility to households, all contracted or quota products, the products of remaining collective operations (such as handicraft workshops) and products from joint team-member shared-profit ventures are handed over to the collective for unitary distribution. In most cases of quota agreements (as opposed to contracts) the whole product is handed over.

Provincial and local stipulations on these questions vary a good deal, but this is the essential position of the collective in the contract system. The collective remains owner, planner, accumulator and distributor, and although collectivism has been relaxed it has by no means been destroyed.

The perspective of future change also remains firmly socialist. The contract system, including contracting to households, is regarded as a new and better beginning for the gradual building up as technology changes of a true system of socialist division of labour and specialisation.

The assignment of full responsibility to households is clearly a different matter, and difficulties are already appearing. Offered the opportunity of restored independence, peasants in many parts of China have responded by returning collective property to individual ownership - even sometimes destroying what cannot be distributed. Some are stubbornly 
planting what they choose to plant, or refusing to plant at all and taking up non-agricultural occupations. They are refusing to contribute to the upkeep of cadres, teachers and paramedics. Often rural cadres, caught between insistence from above that the peasants must be allowed to choose the responsibility system they want, and the determination of many peasant communities to choose whatever gives them the most independence, resign their posts or cease to lead, leaving the way free for the re-assertion of individual farming. The national leadership has moved - or has been pushed - from the concession of restored family farming only to remote and scattered households to consenting to its extension to the poorest villages, to acceptance that this would in fact involve $100 \mathrm{mn}$ farming households, to admission that full responsibility 'is the system preferred by the masses', to a point at which collectivised agriculture, in any sense recognised in the past, may well come to apply only to a minority of China's peasants.

It may be that the new leadership is providing a further illustration of that old political saw, that the most dangerous time for an authoritarian regime is when it starts to reform; it may have aroused, in its attempts to replace collective management by contract, expectations which it cannot control.

On the other hand, there may be more deliberation in the process than is admitted. In October 1980, Red Flag referred with admiration to the Danish agricultural system [Yu Gaoyao 1980]. This was in a context which showed plainly that an analogy was perceived between the Danish system and the new responsibility system; and it was followed by the assertion that the latter could be the foundation of a Chinese style of socialist agriculture. The Danish system, of course, is one of independent agricultural producers operating within a framework of cooperative supply, processing, marketing, credit and research and development, and linked to these cooperatives by contract.

Is this what Deng Xiaoping has in mind?

\section{References}

Guangming Ribao, 1980, S/6437/BII/5, 10 May

NCNA $, 1980, \mathrm{~S} / 6570 / \mathrm{C} 1 / 1,5$ November

Renmin Ribao, 1980a, F/101/L.11, 15 December
- 1980b, S/6427/BII/1, 14 March
$-1980 \mathrm{c}, \mathrm{F} / 253 / \mathrm{L} 42,12$ December
- 1980d, S/6427/BI/1, 14 May
- 1980e, F/205/L13, 13 October
- 1981a, F/174/K7, 1 September
- 1981b, S/6666/BII/1, 2 March
Shanxi Ribao, S/6774/BII/9 nd

Yu Gaoyao, 1980, 'Some facts concerning the orientation of our agricultural production', Red Flag, 5, 19 October S/6572/C.5. 